\title{
BIOACTIVE MILK PEPTIDES: Redefining the Food-Drug Interphase - REVIEW Part 1. Antimicrobial and Immunomodulatory Peptides
}

\author{
Cheison $\mathrm{SC}^{1}$ and Wang $\mathrm{Z}^{1}$
}

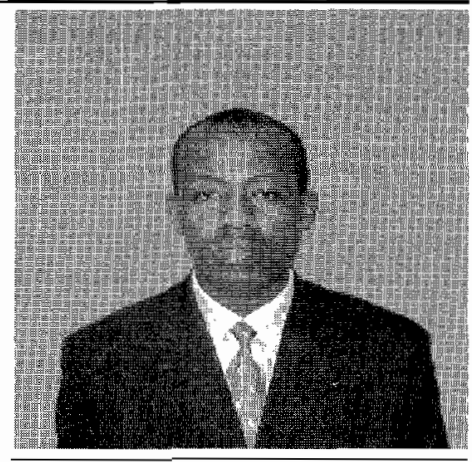

\section{ABSTRACT}

Seronei Cheison

In a three part series, we set out to summarize the data available from various research efforts into the bioactive components resulting from milk protein hydrolysis. Milk contains within itself as an original package a cache of bioactive substances that derive from its secretion. Advances in molecular understanding of processes and enzyme technology have provided new insights into products of milk protein hydrolysis, both by the enzymes and during processing. These products of food digestion and enzyme hydrolysis and processing have been shown to have antimicrobial, immunopotentiating, opioid, Angiotensin Converting-I-Enzyme inhibitory activities as well as some antithrombotic peptides. Furthermore, some peptides have been shown to have mineral binding properties owing to phosphorylation, and have been designated as caseinophosphopeptides.
These are derived from such protein fractions as casein with no known bioactivity in its native form. Whether these derivatives will replace drugs entirely in the immediate future is still unclear, but the increasing appreciation of nutraceuticals will play a complementary rather than a substitutional role to the synthetic pharmacological drugs. This paper is the first part and seeks to review the bioactive milk peptides with emphasis on the immunopotentiating and antimicrobial properties including their applications in novel nutraceuticals.

Keywords: Bioactive peptides, Angiotensin-Iconverting enzyme, (ACE), nutraceuticals, immunomodulatory, antimicrobial peptides, functional foods.

\section{PEPTIDES DE LAIT BIOACTIF: REDEFINITION DE L'INTERPHASE ALIMENT MEDICAMENT - EXAMEN \\ PARTIE 1. PEPTIDES ANTIMICROBIENS ET IMMUNOMODULATOIRE}

\section{Resume}

Dans une série en trois parties, nous faisons un récapitulatif des données disponibles sur diverses recherches menées à propos des composants bioactifs résultants de l'hydrolyse de protéine du lait. Le lait

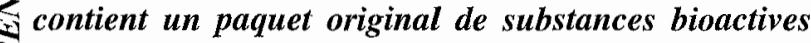
qui proviennent de sa sécrétion. Les avancées enregistrées en technologies moléculaire et enzymatique ont fourni de nouveaux indices sur l'hydrolyse de protêine du lait tant sur les enzymes que le mécanisme. Ces produits de digestion alimentaire et de l'hydrolyse par l'enzyme ainsi que le processus ont été démontré avoir des propriétés antimicrobiennes, potentiel immunitaire, opioüde, et inhibitrice de l'enzyme de conversion de l'Angiotensine

\footnotetext{
*Corresponding author

${ }^{1}$ Southern Yangtze University- (formerly Wuxi University of Light Industry),

School of Food Science \& Technology,

Jiangsu Province Wuxi- 214036, China

Correspondence to: S.C. Cheison Tel.+86 139215 01715, Fax +865105861034.

E-mail: chelulei2000@yahoo.com
}

I ainsi que quelques peptides antithrombotiques. En outre, il a été démontré que certains peptides possèdent des propriétés de fixation de minéraux par le biais de phosphorisation et sont désignés comme caséinophosphopeptides.

Ceux - ci sont dérivés de fractions protéiques telles que la caséine n'ayant aucune bioactivité dans leurs formes natives. Quant à savoir si ces dérivés remplaceront complètement les médicaments dans un futur proche cela n'est pas encore sûr, mais cet engouement pour les neutraceutiques aura un rôle de complémentarité plutôt que de substitution des produits pharmaceutiques de synthèse. Cette publication est le premier versement et vise à passer en revue les peptides bioactifs du lait avec un accent particulier sur le potentiel immunologique et les propriétés antimicrobiennes y compris leurs application en nouvelles neutraceutiques.

Mots clefs: Peptides bioactifs, enzyme de conversion Angiotensine - I (AS) Neutraceutiques, immonomodulatoire, Peptides antimicrobiens, Produits Alimentaires fonctionnels. 


\section{INTRODUCTION}

Milk is a polyphasic secretion of the mammalian glands, and remains one of the most elaborately studied of human food. Its composition within any mammalian species is indicative of the neonatal requirements of its offspring, presenting optimum composition of nutrients required during the newborn period of that species. By composition, it is an almost complete nutritional package, supplying both to the mammalian neonates and to humans some invaluable proteins, ranging from 3.0$3.5 \%$ of bovine milk, among other constituents [1].

The milk proteins have broadly been classified into two, based principally on their solubilities at $\mathrm{pH} 4.6$ at $20^{\circ} \mathrm{C}$; caseins are insoluble at their isoelectric point of $\mathrm{pH} 4.6$, and constitute some $80 \%$. There exists within the casein fraction some genetic polymorphism as $\alpha_{s 1}$-casein ( $\alpha_{s 1^{-}}$ $\mathrm{Cn}), \alpha_{\mathrm{s} 2}$-casein $\left(\alpha_{\mathrm{s} 2}-\mathrm{Cn}\right), \beta$-casein $(\beta-C n)$ and k-casein (k-Cn), constituting in ratio 3:0.8:3:1 respectively [2].

The whey proteins are a group of milk proteins that remain soluble in milk or skim milk at the precipitation point of caseins, $\mathrm{pH} 4.6$ at $20^{\circ} \mathrm{C}$. They have further been shown to compose primarily of B-lactoglobulin- B-LG(7-12\% of total skim milk protein), $\alpha$-lactalbumin-

$\alpha$-LA- (2-5\% of skim milk total protein), serum albumin (SA), immunoglobulins- Ig, lactotransferrin (lactoferrinLf) and $\mathrm{B}_{2}$-microglobulin $[1,3]$.

Milk also contains some natural bioactive substances, which are extant in it by virtue of the physiological origin during secretion. These include oligosaccharides, fucosylated oligosaccharides, hormones, growth factors, mucin and gangliosides, and endogenous peptides, which are present in milk at secretion. Nature factored these substances into milk with a scheduled significance; they support two lines of defences [4]. It would seem the first is an elaborate provision for milk's initial selfdefense against the degradative army of microorganisms while the second offers the first line shield for the neonate. Among the former are lysozyme and lactoperoxidase [5].

Lysozyme works by lysis of the bacterial cell wall, though not without the synergistic effect of the immunoglobulins and lactoferrin, just as so does lactoperoxidase [5]. What has come to be called the lactoperoxidase system deserves if only a fleeting mention because of its significant role in antibacterial activity in milk. Like lactoferrin, it is a glycoprotein with molecular weight of about $80 \mathrm{Kda}$ but unlike the former, it contains one haeme group. An excellent review, beyond the scope of the present paper exists, but suffice it to mention that plausible attempts have been made to explain the action of this system [6]. It is postulated that lactoperoxidase catalyses the oxidation of the thiocyanate ions ( $\mathrm{SCN}$-) forming the hypothiocyanite (OSCN-), which has antibacterial properties [7]. The lactoperoxidase system has been characterized further and shown to supersede the germicidal action of hypothiocyanite alone with lactoperoxidase, $\mathrm{SCN}$ - and hydrogen peroxide $\left(\mathrm{H}_{2} \mathrm{O}_{2}\right)$ as well as higher oxyacids of thiocyanate such as $\mathrm{HO}_{2} \mathrm{SCN}$ and / or $\mathrm{HO}_{3} \mathrm{SCN}$. They all act in concert in this antibacterial package to provide the neonate and the mammary gland with the vital protection against various infective microbes [5].

The second group is defense provision for the neonate and consists prominently of a coterie of immunoglobulins. Furthermore, there are also the neuroactive peptides such as bradykinin, which play a fundamental role in the functioning of the nervous system such as the regulation of pain perception [4].

This paper will be devoted to the bioactive products of native casein and whey protein hydrolysis, which, in their native form, do not possess any discernible bioactivity but become trophically activated following action by proteolytic enzymes either in the process of digestion or during food manufacturing processes. There have emerged in the last couple of decades a number of reports of milk proteins releasing some peptides with characteristic bioactivities not possessed by the precursor proteins and this has led to increased attention from researchers zeroing in on the action of various enzymes and isolation of the hydrolyzed peptides for further characterization. With strides that have been made in molecular elucidation of analytical procedures and advances made in enzyme technology and protein chemistry offered by the countless panoply of modern analytical instrumentation, it has become possible to release and identify bioactive peptides sequestered in inert native proteins, which become trophically activated by proteolytic activities during digestion or during processing [8]. Bioactive peptides have been reported in cheeses at various stages of ripening as well as in fermented milks as well as other food proteins indicating that they are indeed products of food processing $[9,10]$.

Bioactive peptides have amino acid residues ranging in the order of 2-20 and although they have been characterized from other food protein sources, milk remains the paramount provider of the wide array of those elucidated. Investigations in vitro have been carried out to hydrolyze the proteins of milk to yield a variety of bioactive peptides. Recently, with progress made in chemical analysis, they have been isolated from fermented milk, cheese and even in vivo in humans following ingestion of a casein or milk containing diet [11].

The rise in interest in research into physiologically peptides was instigated by the rise in the school of thought that propounds the theory that food serves 
much more than the traditional roles ascribed to it, i.e. nutrition and preference and that in addition it possesses a tertiary function. This function was aptly defined as the ability of a food to lie strategically between drugs and conventional foods, giving rise to the idea of functional foods that provide protection against diseases [12]. Much work in the area of functional foods and bioactive components have been initiated in Japan, which still leads the EU and USA in the opportunities for innovations in this respect. The rise in the application of functional foods has been motivated by increasing consumer selectivity and demand for natural components and/or their derivatives and the minimization of the use or, complete avoidance, of chemical and synthetic components in foods.

This is definitely redefining the traditional role of food as a supplier of nutrient per se and giving rise to a renewed focus on functional foods. These are foods, which, over and above their supply of the requisite nutritional needs, also impart the desirable attribute of physiological benefits. Much of the research in the physiological effects of bioactive peptides has been carried out with in vitro tests with results extrapolated to relate to human cases. The overriding assumption is that the functional peptides or their derivatives resist further hydrolysis in the human digestive tract, and are absorbable in their active form transferred to the target peripheral organs where the desirable physiological effects occur. It has been argued that short peptides with two or three amino acid residues are absorbed in the intestines without further degradation by the digestive enzymes [13]. Before it can be proven that dietary proteins are absorbed after digestion in longer peptides than the di- and tri-peptides, it would seem the activities of these peptides are enteric in their physiological functions and are no less important because they may contribute to a modulation of the microbial ecology and thus favour the desirable microbiota, such as Bifidobacteria, at the expense of the harmful pathogens.

The utilisability of some or all of these peptides derived from proteolysis or synthesized structural analogues as new drugs have given a renewed impetus to intensive collaborative research between academia and industry with government moderating the legal frameworks within which the emergent areas can operate. The increasing need and indeed demand by the consumer and consumer watchdogs for manufacturers to move away from the use of chemicals in processing and or food preservation has renewed the interest in the area of antibacterial bioactive peptides for possible replacements of the traditional preservatives of food [14]. Bioactive peptides are, therefore, increasingly finding extensive use both in applications as additions in functional foods and in the pharmaceutical industry and agriculture, what with the enormous progress made in genetic engineering which means transgenic plants will be engineered to express these peptides [15]. Whether this method will only be limited to expression of disease suppressing peptides or it will be employed to produce en masse the peptides for economic reasons is not far fetched.

This paper is by no means an exhaustive catalogue of the bioactive peptides so far characterized. There are new peptides being revealed each time, assisted by new methodology evolving in peptide and amino acid technology. It is intended, however, to arouse interest in the African research community, whose voice has not been heard or is significantly small and it is hoped that this will give a clarion call to focus on the benefits of nutraceuticals.

There are still some grey areas in the research in bioactive peptides and the contentions exist with regard to whether they are generated in significant physiological levels during in vivo digestion or during food processing.

\section{IMMUNOSTIMULATING PEPTIDES}

At birth, the mammalian neonate immunocompetent cells result in specific defects such as decrease in the polymorphonuclear leukocyte (PMNL) number and in some of their phagocytic functions namely chemotaxis, internalization and killing capacity. Breast-feeding overcomes these deficiencies by providing a variety of protective factors and cells that have a direct effect on the newborn's resistance to bacterial and viral infections [16].

Immunostimulating peptides (variously named immunomodulatory or immunomodulating) derived from milk affected both the immune system and the cell proliferation responses, and were identified from sequences corresponding to fragments f194-199 of $\alpha_{\mathrm{s} 1^{-}}$ casein (Thr-Thr-Met-Pro-Leu-Trp). They have also been reported from fragments f63-68 and f191-193 of B-casein, which composed of amino acid residues Pro-Gly-Pro-IlePro-Asn and Leu-Tyr-Glu, respectively [17]. The $\alpha_{\text {sI- }}$ casein fragment $1194-199$ and the $B$-casein fragment f193-202 ( $\alpha_{\mathrm{s} 1}$-Casokiı $\alpha_{1}$ and $\beta$-Casokinin, respectively) are also Angiotensin-I-Converting-Enzyme, (ACE) inhibitors. This interplay of physiological effects of the

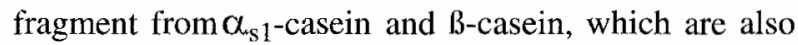
ACE inhibitors, as immunopotentiating peptides must not be overlooked since this vividly underscores the import of a peptide exerting several physiological effects or as may be probable, the interaction of several peptides in a defined physiological aspect $[9,18]$. Migliore-Samour et al. [18] named this part of the BCn molecule a 'strategic zone' owing to apparent significance because cleavage of whatever bond does not render the resulting peptide physiological 
insignificant, instead conferring on it characteristic functionality, either as an opioid peptide or immunomodulatory.

Since B-Casokinins inhibit ACE that is responsible for inactivating bradykinin, a hormone with immuneenhancing features, then this (ACE-inhibitory) peptide indirectly elicits an overall immunostimulating response. ACE catalyses the activation of angiotensin II and in this while inactivating bradykinin, a vasodilator [16]. Bradykinin stimulates macrophages to enhance lymphocyte migration and to increase secretion of lymphokines. An ACE inhibitor, therefore, would favour bradykinin thus conferring an overall immunomodulatory effect [16]. Casein-derived immunopeptides instigate the phagocytic activities notably of human macrophages against senescent (aging) red blood monocytes and macrophages, and augment phagocytosis of sheep red blood cells by murine peritoneal macrophages in vitro. There was an increase in activity starting with doses as low as $0.2 \mu \mathrm{M}$ and it was dose dependent. They were also shown to protect against Klebsiella pneumoniae infection in mice when treated intravenousily with the B-casein hexapeptide Val-Glu-Pro-Ile-Pro-Tyr derived from the human casein digests [16-19]. It was effective even at a dose of $0.5 \mathrm{mg} / \mathrm{Kg}$. An ACE inhibitor with the amino acid residues Thr-Thr-Met-Pro-Leu-Trp had earlier been shown to exert immunopotentiating effects from bovine casein enzymatic digests. This peptide at levels as low as $0.05 \mu \mathrm{M}$ stimulated murine peritoneal macrophages in another study [16].

In a recent study, some lactoferrin fragments liberated by pepsin conferred immunomodulatory effects on murine splenocytes and Peyer's Patch Cells [20]. Although the researchers were not able to isolate the peptides for characterization, they showed that the lactoferrin peptic hydrolysate had a stimulatory effect on the proliferation of splenocytes. Because lactoferrin is digested by pepsin in the stomach after oral administration, it apparently has potential to function as an immunostimulator in vivo.

The immunopotentiating peptides Tyr-Gly from bovine a-lactalbumin and Tyr-Gly-Gly from k-casein were found to be active components in a dialyzed leukocyte extract from normal donors that were used in a large multicentre trial to inhibit the development of infections in patients with pre-Acquired Immune Deficiency SyndromeAIDS [21]. It was reported that the immunoreactivity of human peripheral-blood lymphocytes (PBL) were either stimulated or suppressed by various bioactive peptides derived from milk proteins [22]. The two peptides above were found to significantly enhance the proliferation of PBL at concentrations that were in the order of $10^{-11}$ to $10^{-4} \mathrm{~mol} / \mathrm{L}$. The $\kappa$-casein derivative revealed $74 \%$ of maximal stimulation at $10^{-12} \mathrm{~mol} / \mathrm{L}$ whereas the a-casein derivative showed a $93 \%$ maximal stimulation at $10^{-9} \mathrm{~mol} / \mathrm{L}$. It was further deduced that depending on their concentrations, B-casokinin-10 and ß-casomorphin-7 peptides showed a suppression as well as stimulation of lymphocyte proliferation [22].

Interestingly B-casomorphin-7 ( $\mathrm{Tyr}_{60}-$ Pro-Phe-Pro-GlyPro $_{65}-\mathrm{Ile}_{66}$ ) reported as an opioid peptide was also shown in a study to inhibit the proliferation of human colonic lamina propria lymphocytes which effect was reversed by the opiate receptor antagonist, naloxone [23]. Although there is still some equivocation regarding the structure-activity and the mechanism by which milk bioactive peptides exert their immunomodulatory effects, results from this particular study did point strongly to the fact that opioid peptides could affect the immunoreactivity of lymphocytes via opiate receptors. It has been suggested that these peptides stimulate the neonate's immune system and may be useful in resistance by adults to bacterial and viral attacks. The relationship between opioid peptides and immune system is remarkable, where the opioid $\mu$-receptors for endorphins have been found on $T$ lymphocytes and human phagocytic leukocytes, meaning they have endorphinlike activity with respect to the development of T-cell functions and cellular immunity. It is further known that lymphocytes and macrophages display receptors for a number of biologically active mediators [8].

Multifaceted approaches have been adopted to combat the AIDS pandemic ranging from enzyme inhibitors to immune enhancement. A recent patent claimed that a therapeutically effective amount of peptides from the $\mathrm{N}$-terminus of as 1-Cn could be used in a pharmaceutical formulation to prevent or treat AIDS [24]. Indeed, could milk have significant products of enzyme hydrolysis that can help prevent or reduce the AIDS symptoms? It would seem that it does contain peptides that are important but levels of the same are not easy to determine.

\section{ANTIMICROBIAL PEPTIDES}

Milk offers an increased antimicrobial effect that surpasses the sum of the individual contribution of the cache of immunoglobulins and other defence proteins. This has been attributed in part to their synergy, and additionally to the presence of natural antibacterial proteins, notably lysozyme and the so-called lactoperoxidase system and to the derivatives of protein proteolysis [5]. Most of the antimicrobial peptides were derived from the whey protein lactoferrin, a bilobate iron-binding glycoprotein, of about $80 \mathrm{kDa}$ present in tears, synovial fluids, saliva, seminal fluids and milk. Native lactoferrin has bacteriostatic and bactericidal activity, which has been attributed to its ability to bind iron, owing to its ability to avidly bind the iron necessary for bacterial growth and virulence [25]. However, discoveries by Bellamy et al. [26] of the 
existence of an antimicrobial sequence in a region distinct from its iron-binding site shifted focus to another quality of lactoferrin hitherto uncharacterized. The potent bactericidal peptide specifically generated by pepsin digestion of bovine lactoferrin, and named lactoferricin ${ }^{\circledR} \mathrm{B}$ (Morinaga Milk Industry Company Ltd, Japan), showed significant antimicrobial activity against Gram-positive and especially Gram-negative bacteria. The sequence was found at the $\mathrm{N}$-terminal region corresponding to a 25-amino acid moiety identified as fragments f17-41; Phe-Lys-Cys-Arg-Arg-Trp-Gln-TrpArg-Met-Lys-Lys-Leu-Gly-Ala-Pro-Ser-Ile-Thr-Cys-ValArg-Arg-Ala-Phe. This polypeptide has been characterized in vivo following oral administration of lactoferrin and ostensibly it is produced during enzymatic digestion of a lactoferrin containing diet in the human digestive tract [11].

Furthermore, Bellamy et al. [14] studied the effect of this peptide under various environmental conditions using 31 strains of bacteria and found out that it was ten times more potent than native lactoferrin. They found out that autoclaving it at $121^{\circ} \mathrm{C}$ for example for 15 minutes at $\mathrm{pH} 3$ to 7 did not reduce the germicidal effectiveness.

This peptide was similar to lactoferricin $\mathrm{H}$, a 33-amino acid residue peptide derived from human lactoferrin meaning that the antimicrobial domain for this protein exists in basically the same region. The antimicrobial sequence was further found to be devoid of tyrosyl and histidyl residues, which have been shown to participate in iron chelating, excluding the iron sequestering property in the germicidal effectiveness of this peptide. The researchers did find a characteristically high conglomeration of highly basic amino acids (32\% of the 25 residues) leading to the conclusion that the cationic nature of the peptide was inevitably the premise upon which it is injurious to the bacterial cell wall. The cationic property is similar to that of magainins, cecrophins and defensins, which are known to function because of their affinity for negatively, charged phospholipids and lipopolysaccharides of biological membranes [27-29]. The lethality of doses were straindependent and the Gram-positive bacteria were found to be differentially more susceptible to lactoferricin that native lactoferrin owing to the structure and presence of higher amounts of certain negatively charged cell wall components, such as teichoic acids or teichuronic acids which could potentially bind this cationic peptide $[27,29]$.

Zhang et al. [30] reported that lactoferricin $\mathrm{H}$ neutralized endotoxins by binding to the endotoxin lipopolysaccharide, a major pathogenic factor of Gramnegative septic shock, while another $\mathrm{N}$-terminus derived peptide of the human lactoferrin was found to be effective in vitro against infections with antibioticresistant $S$. aureus and $K$. pneumoniae [23]. This study found out that when the lactoferrin lacked the first three residues from the $\mathrm{N}$-terminus, the bactericidal effectiveness was reduced, further prove that the basic residues are essential for activity- in this case the arginyl residues. Other researchers found and reported antimicrobial activity of lactoferricins towards enterotoxigenic Escherichia coli (particularly E. coli 0111) [25]. There have been reported successes in trials of this peptide against strains of Bacillus, Streptococcus, Salmonella, Proteus and Pseudomonas [32]. In antifungal trials, these peptides were found to be potent against filamentous fungi including dermatophytes [33], whereas when used in a cocktail with triazoles, derivatives of lactoferrin inhibited growth of azole-resistant Candida albicans hyphae [34]. Milk, therefore does have peptides that show marked potency against fungal flora. There are methods now in place for the commercial production of both lactoferrin and lactoferricin, with the latter being handled at proprietary level [35].

In a study, Yamauchi et al. [29] reported successes with both lactoferrin and lactoferricin $\mathrm{B}$ and demonstrated their effect on intrinsically labelled $\left[{ }^{3} \mathrm{H}\right]$ lipopolysaccharide using three strains namely, $E$ coli CL99 1-2, Salmonella typhimurium SL696 and Salmonella montevideo SL 5222 and showed that more lipopolysaccharide was released by the peptide under each condition of study that when lactoferrin was used. This study bolstered the claim that lactoferrin and lactoferricin have antibacterial activity stemming out of a property that supersedes mere sequestering of iron, and that as a cationic peptide it is injurious to the cell wall of bacteria $[27,28]$. Lactoferrin was also found to be consistently bacteriostatic whereas lactoferricin was bactericidal against these Gram-negative strains.

Although much more needs to be done on the discrimination of the essential probiotics it was found that strains of Bifidobacteria showed no detectable loss of viability over the 60 minutes during which the study microbes were exposed to the peptides, as is evident in data presented in Table 3 .

This should further strengthen the application of lactoferricin as a natural preservative in food or in various applications in the pharmaceutical industry without risking an upset of the gut microbial ecology, since there is no undue risk to the Bifidobacteria resident in the human digestive tract.

Caseins have also been reported to possess latent antimicrobial peptides, which are released by enzyme activity. Casecidin, a product of chymosin hydrolysis of casein at neutral $\mathrm{pH}$, was shown to be active during in vivo studies against Staphylococcus, Sarcina, 
Bacillus subtilis, Diplococcus pneumoniae and Streptococcus pyogenes [4]. The $\alpha_{\mathrm{s} 2 \text {-casein cationic }}$ fragment casocidin-I (f165-203) containing a high proportion (10 of 39) of basic amino acid residues was found to inhibit the growth of Escherichia coli and Staphylococcus carnosus [36]. Yet another plus was observed when isracidin, a derivative of $\alpha_{s} 1^{-c a s e i n, ~ w a s ~}$ injected into the udder of sheep and cow, at levels comparable to those used with standard antibiotic treatment, with protection against mastitis observed [4].

\section{FUNCTIONAL FOODS AND NUTRACEUTICALS, THE HORIZON OF POSSIBILITIES}

Specific diets and functional foods have gained importance in use tremendously for prevention and treatment of diseases and improving the body's functions. Supplements have increasingly gained applicability owing to the understanding that no single food contains all the desirable nutriments required by the body. The use of peptide mixtures and protein hydrolysates as nitrogen sources in the formulation of foodstuffs for patients suffering from malnourishment and problems of protein digestion or absorption should find increasing acceptability and displace the application of free amino acids or polypeptide mixtures. This is because peptides are less hypertonic than free amino acids, which increases their absorption efficiency and in addition reduces the osmotic problems. Moreover, because of the probable physiological functionality of peptides, they may elicit some desirable functional property, however transient, before they are hydrolyzed to yield the requisite amino acids.

A nutraceutical has been defined as any product that has been isolated or purified from food, is generally sold in a medicinal form not usually associated with food and has physiological benefit or provides protection against chronic disease. That food can entirely replace prescription drugs is not feasible, at least not now. It is envisaged, however, that with increasing awareness and the speed with which scientific consumerism is fast catching up with the dinner table, the need for functional foods to break the curtain of mere satiety and incorporate value-added physiological effects will gain momentum and food will gain a role as a complementary drug. A vivid distinction will increasingly be vague regarding the line between health-enhancing nutraceuticals and those consumed for pharmacological needs.

Medical foods are different from functional foods, the former being designed to supply missing nutriment and are supplements or are meant for patients of diet related diseases. Functional foods have gained an enviable ground in Japan and the wealthy nations are ever bearing the pressure from consumers who demand that food manufacturers should, after processing of safety into food, as well as formulating for the incorporation of healthful and functional constituents.

Lactoferricin, which is commercially available, has been suggested for use in combating cancer, inflammations and infections or antibiotic resistant microbial flora and recently it has even found use in the agricultural sector for combating fungal nuisance in crops where plants are genetically engineered to express the peptide transgenically [27, 35-37]. It was proposed that this peptide could also be used in cosmetic, eye-care, oral hygiene products, skin care products and pet food and hygiene applications [35].

Indeed some of these are in place already and when asked about the taste effects of lactoferricin, Dr. Susumu Teraguchi, based at the inventor's laboratory, at Morinaga Milk Co. Ltd, Japan, was of the opinion that although it may be a bitter peptide, although the levels applied would not necessarily meet the perceptible threshold.

Innovations regarding the commercial production of immunomodulating peptides of milk origin have emerged and it is postulated that these peptides will play a role in pharmaceutical formulations that can, inter alia, enhance hematopoiesis, prevent viral infections or modulate the development of autoimmune diseases. It is further suggested that the same products can be offered for prevention and/ or treatment of AIDS [24]. Much as some questions remain unanswered, it is an inspiring area especially regarding the potential for our universities to raise money through inventions, and donor funding will be encouraged towards local nutritional research as pertains to alleviation or complete elimination of the problems attending to nutritional deficiencies and relationships to disease prevention.

Where cost is a factor synthetic analogues can be made, and are indeed available, with modifications to enhance their bioactivity. It is not clear yet whether these modifications and subsequent augmentation of their bioactivity will not upset the delicate balance designed by nature in the potency of the natural peptides and research opportunities abound.

It is tempting to ask: Do those who take milk and milk products have better chances of health than those who do not? It is not preposterous to claim that little is better than none at all! Obviously there is a long and arduous road to complete claim of the presence of the bioactive peptides in the human consumer following consumption of milk or milk containing diet, however ephemeral the sojourn is, but encouraging analytical techniques in protein chemistry are evolving by the day.

Neither will it be easy even when these peptides are 
demonstrated to be present the levels required to elicit a significant physiological effect. The presence of these desirable products of digestion, however, will give impetus to the increasing interaction between pharmaceuticals and the food industry, and those foods that contain these components will be encouraged for consumption as functional foods. Pertinent questions attending these inventions such as: are they of a toxicological acceptability and what do they portend for the milk consumer in terms of the levels available from consumption of milk; indeed are heavy milk consumers any different from non-consumers at all? While it is tempting to turn polemic for defense of these peptides since they derive from food and are not 'foreign' in the sense of chemical additives, no published toxicological data hitherto exist. Bellamy et al. [14], however argued that since they are part of the food and are not foreign they may not pose any real danger to the consumer. We buy this argument, save for any discounting data to the contrary and hope that investigations in the food additive area would be pricked to attempt the toxicological studies. Furthermore, these peptides have been found as products of proteolytic activities of food grade, generally regarded as safe (GRAS) microorganisms used in food production and which implies that safety is not at risk of being compromised.

The trial of lactoferricin in combating enterohaemorrhagic $E$ coli $0157: \mathrm{H} 7$ in ground beef when studied in $1 \%$ peptone at both $4^{\circ} \mathrm{C}$ and $10^{\circ} \mathrm{C}$ reported reductions of the pathogen were by 0.7 and $2.0 \log \mathrm{CFU} / \mathrm{ml}$ for $50 \mu \mathrm{g}$ and $100 \mu \mathrm{g}$, respectively. At the $\mathrm{pH}$ values of 5.5 and 7.2 values under which the study was conducted, the researchers concluded that the effect did not reveal any significant difference to warrant its use in ground beef. Much remains to be done to ascertain the efficacy of this peptide in food preservation, what levels are required and under what conditions [38]. Although there are identifiable segments that are bioactive in the in vitro trials, it has not been possible to demonstrate that these peptides cross over to the sites where their physiological effects would be desirable. However, shorter peptides of 2 to 3 amino acid moieties have been shown to pass through the intestinal wall and may be assumed to exert the effects that are related to them in the tests.

\section{CONCLUSION}

Excellent reviews [39] have appeared that shed invaluable light on the potentials of bioactive peptides for application in preparation of nutraceuticals but few have had the courage to mention the bottlenecks that still stand in the way of full knowledge and application of the same. It is known that casein and whey proteins and potentially all other proteins have sequences of bioactive peptides within their primary sequences. The rise of customer awareness about the deleterious effects of chemical preservatives and the increasing preference for natural, or 'green', components should give these peptides an ever-increasing role in the field of food preservation and nutraceuticals.

Although the characterization in vivo of these peptides has not been successful for all but a few, this should not discourage investigations. It is hoped that peptides will increasingly replace amino acids as supplementation components and there will emerge an expanded application of these in the pharmaceuticals, while research proceeds to establish other desirable qualities that can be obtained by both chemical and enzymatic modifications.

While the peptides contained in milk, fermented milks and cheeses are not as potent as the medical drugs commonly used in prophylaxis [39], they do regulate particular bodily processes and should therefore catapult the parent foods into more consumption if but to gain the benefits that come therewith. These foods gain acceptance as functional foods and should provide a new convergence for food science, pharmaceutical industry and nutrition.

Exciting areas of enquiries exist in certain nutritional habits regarding the fate of the proteins, given for example communities in Africa that consume a cocktail of blood and fermented milk, where investigations should be encouraged to determine the resulting peptides of this, and what effect it may exert on the consumer. Opportunities for research abound in the African dairy landscape owing to the variety of sources of milk consumed. It is hoped that interest will be ignited in investigators to look into the fate of milk proteins from as diverse sources as sheep and goats and camel milk. This should help illuminate the benefits deriving from the same that do enhance disease prevention in the remote communities that consume these milks.

While the pharmaceutical industry grapples with innovations to tap the benefits of nutraceuticals and particularly milk derived bioactive peptides, it is hoped that milk will continue to find increasing use in its variety of available products and that the functional and physiological properties of its proteins and products of hydrolysis in the consumer's gut will exert a net disease suppressing effect, making it an invaluable and cheap functional food. In the next sequel, we set out to cover the mineral binding, casein phosphopeptides and opioid peptides while the third and final instalment will be dedicated to the ACE inhibitory peptides as weil as antithrombotic peptides. 


\section{REFERENCES}

1. Eigel WN, Butler JE, Ernstrom CA, Farell HM, Harwalkar VR, Jennes $R$ and $R$ Whitney Nomenclature of Proteins of Cow's Milk: 5th Revision. J. Dairy Sci. 1984; 67: 1599-1631.

2. Schmidt DG Association of Caseins and Casein Micelle Structure. In: PF Fox (Ed). Developments in Dairy Chemistry-1: Proteins. London: Elsevier Applied Science. 1982; pp 61-86.

3. Swaisgood, HE Chemistry of Milk Proteins.In: PF Fox (Ed). Developments in Dairy Chemistry1: Proteins. London: Elsevier Applied Science. 1982; pp 1-59.

4. Lahov $\mathbf{E}$ and $\mathbf{W}$ Regelson Antibacterial and Immunostimulating Casein-derived Substances from Milk: Casecidin, Isracidin Peptides. Food Chem. Toxicol. 1996; 34: 131-145.

5. Bjorck $\mathbf{L}$ Lactoperoxidase..In: PF Fox (Ed). Advanced Dairy Chemistry-1: Proteins. London: Elsevier Applied Science. 1992; pp 332-338.

6. Pruitt KM and $J$ Tenovuo (Eds) The Lactoperoxidase System: Chemistry and Biological Significance. New York: Marcel Dekker Inc. 1985.

7. Reiter $B$ and $\mathbf{G}$ Härnulv Lactoperoxidase Antibacterial System: Natural Occurrence, Biological Functions and Practical Applications. J. Food Prot. 1984; 47: 724-732.

8. Meisel $H$ and $E$ Schlimme Milk Proteins: Precursors of Bioactive Peptides. Trends Food Sci. Tech. 1990; 1: 41-43.

9. Gobbetti M, Stepaniak L, De Angelis M, Corsetti $A$ and $R$ Di Cagno Latent Bioactive Peptides in Milk Proteins: Proteolytic Activation and Significance in Dairy Processing. Crit. Rev. Food Sci. Nutr. 2002; 42: 223-239.

10. Smacchi $\mathbf{E}$ and $\mathbf{M}$ Gobbetti Bioactive Peptides in Dairy Products: Synthesis and Interaction with Proteolytic Enzyme. Food Microbiol. 2000; 17: 129-141.

11. Kuwata H, Yip TT, Tomita M and W Hutchens Direct Evidence of the Generation in the Human Stomach of an Antimicrobial Peptide Domain (Lactoferricin) from Ingested Lactoferrin. Biochem. Biophys. Acta. 1998; 1429: 129-141.

12. Arai $\mathbf{S}$ Studies on Functional Foods in JapanState of the Art. Biosci. Biotech. Biochem. 1996; 60: $9-15$.
13. Mayes PA Nutrition, Digestion and Absorption. In: Murray et al., (Eds). Harpers Biochemistry. Appleton \& Lange. USA. 1999.

14. Bellamy WR, Takase M, Wakabayashi H, Kawase $K$ and $M$ Tomita Antibacterial Spectrum of Lactoferricin B, a Potent Bactericidal Peptide Derived from the N-terminal Region of Bovine Lactoferrin. J. Appl. Bacteriol. 1992; 73: 472-479.

15. Vernooli BTM, Clare DA, Chandler DB and CM Cramer Peptide with Inhibitory Activity Towards Plant Pathogenic Fungi. Int. Patent Applic. No. 1998; PCT/EP97/04438.

16. Fiat AM, Migliore-Samour $D$, Jollès $P$, Drouet $\mathrm{L}$, Sollier CBD and J Caen Biologically Active Peptide Peptides from Milk with Emphasis on Two Examples Concerning Anti-thrombotic and Immunomodulating Activities. J. Dairy Sci. 1993; 76: 301-310.

17. Parker F, Migliore-Samour D, Floch F, Zerial A, Werner GH, Jollès J, Casaretto M, Zahn $H$ and $P$ Jollès Immunostimulating Hexapeptide from Human Casein: Amino Acid Sequence Synthesis and Biological Properties. Eur. J. Biochem. 1984; 145: 677-682.

18. Migliore-Samour $\mathbf{D}$, Floch $\mathbf{F}$ and $\mathbf{P}$ Jollès Biologically Active Casein Peptides Implicated in Immunomodulation. J. Dairy Res. 1989; 56: 357 362.

19. Jollès P, Parker F, Floch F, Migliore-Samour D, Alliel P, Zerial $A$ and GH Werner Immunostimulating Substances from Human Casein. J. Immunopharmacol. 1981; 3: 363-369.

20. Miyauchi H, Kaino A, Shinoda I, Fukuwatari $Y$ and $H$ Hayasawa Immunomodulatory Effect of Bovine Lactoferrin Pepsin Hydrolysate on Murine Splenocytes and Peyer's Patch Cells. $J$. Dairy Sci. 1997; 80: 2330-2339.

21. Meisel $\mathbf{H}$ and $\mathbf{W}$ Bockelmann Bioactive Peptides Encrypted in Milk Proteins: Proteolytic Activation and Thropho-Functional Properties. Antonie van Leeuwenhoek 1999; 76: 207-215.

22. Kayser $\mathbf{H}$ and $\mathbf{H}$ Meisel Stimulation of Human Peripheral Blood Lymphocytes by Bioactive Peptides Derived from Bovine Milk Proteins. FEBS Lett. 1996; 383: 18-20.

23. Elitsur Y and GD Luk Beta-Casomorphin (BCM) and Human Colonic Lamina Lymphocyte Proliferation. Clin. Exp. Immunol. 1991; 123: 1068-1070. 
24. Sidelman $\mathbf{Z}$ Casein: Derived Peptides and Uses Thereof in Therapy. 2001; World Patent No. WO01/64234A1.

25. Dionysius DA, Grieve PA and JM Milne Forms of Lactoferrin: Their Bactericidal Effect on Enterotoxigenic Escherichia coli. J. Dairy Sci. 1992; 76: 2597-2606.

26. Bellamy WR, Takase M, Yamauchi $\mathbf{K}$, Wakabayashi $H$, Kawaze $K$ and $M$ Tomita Identification of Bactericidal Domain of Lactoferrin. Biochim. Biophys. Acta. 1992; 1121: 130-136.

27. Bellamy WR, Wakabayashi $\mathbf{H}$, Takase $\mathbf{M}$, Kawaze K, Shimamura $S$ and M Tomita Role of Cell-Binding in the Antibacterial Mechanism of Lactoferricin B. J. Appl. Bacteriol. 1993; 75: 478-484.

28. Haukland HH, Ulvatne $\boldsymbol{H}$, Sandvik $\mathbf{K}$ and LH Vorland The Antibacterial Peptides Lactoferricin B and Magainin 2 Cross over the Bacterial Cytoplasmic Membrane and Reside in the Cytoplasm. FEBS Lett. 2001; 508: 389-393.

29. Yamauchi K, Tomita M, Giehl TJ and RT Ellison 3rd. Antibacterial Activity of Lactoferrin and a Pepsin-derived Lactoferrin Peptide Fragment. Infect. Immun. 1993; 61: 719-728.

30. Zhang GH, Mann DM and CM Tsai Neutralization of Endotoxin in vitro and in vivo by a Human Lactoferrin-derived Peptide. Infect. Immun. 1999; 67: $1353-1358$.

31. Nibbering PH, Ravensbergen $\mathbf{E}$, Welling $\mathbf{M M}$, Van Berkel LA, Van Berkel PHC, Pauwels EK and JH Nuijens Human Lactoferrin and Peptides Derived from its $\mathrm{N}$-terminus are Highly Effective against Infections with Antibiotic Resistant Bacteria. Infect. Immun. 2001; 69: 1469 1476.

32. Tomita M, Bellamy WR, Takase M, Yamauchi K, Wakabayashi $\mathbf{H}$ and Kawaze $\mathbf{K}$ Potent Antibacterial Peptides Generated by Pepsin
Digestion of Bovine Lactoferrin. J. Dairy Sci. $1991 ; 74: 4137-4142$.

33. Wakabayashi H, Abe S, Okutomi T, Tansho $S$, Kawase $\mathbf{K}$ and $\mathbf{H}$ Yamaguchi Cooperative Anti-Candida Effects of Lactoferrin or its Peptides in Combination with Azole Antifungal Agents. Microbiol. Immunol. 1996; 40: 821-825.

34. Wakabayashi $H$, Abe S, Teraguchi $S$, Hayasawa $H$, and $H$ Yamaguchi Inhibition of Hyphal Growth of Azole-Resistant Strains of Candida albicans by Triazole Antifungal Agents in the Presence of Lactoferrin-related Compounds. Antimicrob. Agents Chemother. 1998; 7: 15871591.

35. Tomita M, Shimamura S, Kawaze K, Fukuwatari $Y$, Takase $M$, Bellamy WR, Hagiwara $\mathbf{T}$ and $\mathbf{H}$ Matukuma A Process for Large-scale Production of Antibacterial Peptide in High Purity. Eur. Patent Applic 1992; EP 0519726A2.

36. Hanso L, Mattsby-Baltzer I and C Motas Treatment and Prevention of Infections, Inflammations and/ or Tumours with Lactoferrin and/or Lactoferricin. Int. Patent Applic. No. 1998; PCT/SE97/01344.

37. Diarra MS, Lacasse $P$ and D Petitclerc Method and Composition for Treatment and/or Prevention of Antibiotic-resistant Microorganism Infections. Int. Patent Applic. No. 2001; PCT/CA00/01517.

38. Venkitanarayanan KT, Zhao and MP Doyle Antibacterial Effect of Lactoferricin B on Escherichia coli 0157:H7 in Ground Beef. J. Food Prot. 1999; 62: 747-750.

39. Schilmme $\mathbf{E}$ and $\mathbf{H}$ Meisel Bioactive Peptides Derived from Milk Proteins. Structural, Physiological and Analytical Aspects. Die Nahrung 1995; 39: 1-20. 
Table 1

Biologically Active Peptides Derived from Milk Protein Components

\begin{tabular}{|c|c|c|c|c|}
\hline Peptide Sequence & Name & no Acid Segment & Bioactivity & Ref. \\
\hline Try-Gln-Gln-Pro-Val-Leu-Gly-Pro-Val-Arg & B-Casokinin-10 & B-Cn (f193-202) & Immunomod/ACE-In & 20 \\
\hline $\begin{array}{l}\text { Phe-Lys-Cys-Arg-Arg-Trp-Gln-Trp-Arg-Met-Lys-Le } \\
\text {-Gly-Ala-Pro-Ser-Ile-Thr-Cys-Val-Arg-Arg-Ala-Phe }\end{array}$ & $\begin{array}{l}\text { eu- } \\
\text { Lactoferricin B }\end{array}$ & Lf $(f 17-41)$ & Immunomod/Antimic & 29,34 \\
\hline Leu-Leu-Tyr & Immunopeptide & B-Cn (F191-193) & Immunomodulation & 21 \\
\hline Pro-Gly-Pro-Ile-Pro-Asn & Synthetic analogue $\beta$ & ß-Cn $(f 63-68)$ & Immunomodulation & 21 \\
\hline $\begin{array}{l}\text { Arg-Pro-Lys-His-Pro-Ile-Lys-His-Gln-Gly-Leu-Pro- } \\
\text {-Gln-Glu-Val-Leu-Asn-Glu-Asn-Leu-Leu-Arg-Phe }\end{array}$ & Isracidin $\quad 0$ & $\alpha_{\mathrm{s} 1}-\mathrm{Cn} \quad(\mathrm{fl}-23)$ & Antimicrobial & 17 \\
\hline $\begin{array}{l}\text { Lys-Lys-Ile-Ser-Gln-Arg-Tyr-Gln-Lys-Phe-Ala-Leu- } \\
\text {-Pro-Gln-Tyr-Leu-Lys-Thr-Val-Tyr-Gln-His-Gln- } \\
\text {-Lys-Ala-Met-Lys-Pro-Trp-Ile-Gln-Pro-Lys-Thr- } \\
\text {-Lys-Val-Ile-Pro-Tyr }\end{array}$ & Casocidin-I & $\alpha_{s 1}-\mathrm{Cn} \quad(\mathrm{fl} 65-203)$ & Antimicrobial & 42 \\
\hline
\end{tabular}

ACE-In $=$ ACE inhibitor, $\mathrm{LA}=$ Lactalbumin, $\mathrm{LG}=$ Lactoglobulin, $\mathrm{Cn}=$ Casein, $\mathrm{Lf}=$ Lactoferrin.

Three letter codes for amino acids are used. Details are available in the literature cited.

Table 2

Antibacterial effectiveness of bovine lactoferrin (Lf) and lactoferricin $B$ (Lfcin)

\begin{tabular}{|l|l|l|l|l|}
\hline \multirow{2}{*}{ Microorganism } & \multicolumn{2}{|c|}{ Antibacterial effectiveness } & \multicolumn{2}{c|}{ Bactericidal activity CFU/ml } \\
\cline { 2 - 5 } & \multicolumn{2}{|c|}{ MIC $(\mu \mathrm{M})$} & \multicolumn{2}{c|}{ CFU/ml } \\
\cline { 2 - 5 } & Lf & Lfcin & Control & Treated \\
\hline E-coli IID-861 & 25 & 2 & $1.2 \times 10^{5}$ & $<100$ \\
\hline K pneumoniae JCM-1662T & $>100$ & 3 & $3.2 \times 10^{5}$ & $<100$ \\
\hline P aeruginosa IFO-3446 & $>100$ & 3 & $2.6 \times 10^{5}$ & $<100$ \\
\hline S aureus JCM-2151 & 25 & 2 & $2.1 \times 10^{6}$ & 1700 \\
\hline L monocytogenes IDF-1b & 20 & 0.3 & $1.0 \times 10^{6}$ & $<100$ \\
\hline
\end{tabular}

Notes: $\mathrm{CFU}=$ Colony forming units, $\mathrm{MIC}=$ Minimal inhibitory concentration. Klebsiella pneumoniae was cultured at $30^{\circ} \mathrm{C}$ while the others were $37^{\circ} \mathrm{C}$. Adopted from Bellamy et at. [2]

Table 3

Susceptibility of various bacteria to inactivation by lactoferricin $B$

\begin{tabular}{|c|c|c|c|}
\hline \multirow[b]{2}{*}{ Strain } & \multicolumn{3}{|c|}{ Mean CFU/mI } \\
\hline & Control & Treated & Survival $(\%)$ \\
\hline \multicolumn{4}{|l|}{ Gram-Negative Bacteria } \\
\hline E. coli IID-861 & $1.2 \times 10^{5}$ & $<100$ & $<0.08$ \\
\hline Salmonella enteridis IDD-604 & $5.2 \times 10^{5}$ & $1.8 \times 10^{*}$ & 3.5 \\
\hline P. aeruginosa IFO-3448 & $4.2 \times 10^{5}$ & $3.9 \times 10^{3}$ & 0.93 \\
\hline Camp. Jejunt JCM-2013 & $3.1 \times 10^{5}$ & $2.8 \times 10^{3}$ & 0.09 \\
\hline \multicolumn{4}{|l|}{ Gram-positive } \\
\hline Staph. Aureus JCM-2413 & $2.4 \times 10^{6}$ & $4,0 \times 10^{2}$ & 0.02 \\
\hline Enter. Faecalis ATCC-E19433 & $2.0 \times 10^{6}$ & $1.1 \times 10^{6}$ & 55,0 \\
\hline Strep. Mutans JCM 5175 & $3.0 \times 10^{4}$ & $<100$ & 0.33 \\
\hline Strep. Thetmophitus ATCC-19258 & $1.7 \times 10^{4}$ & $<100$ & $<0.59$ \\
\hline Strep, Lactis ATCC-19435 & $2.4 \times 10^{5}$ & $1.0 \times 10^{2}$ & 0,04 \\
\hline List. Monocyogenes JCM-7673 & $5.1 \times 10^{4}$ & $<100$ & $<0.20$ \\
\hline Bacillus subtilis ATCC-6633 & $2.8 \times 10^{5}$ & $<100$ & $<0.04$ \\
\hline Bacillus cereus MM1-272 & $3.2 \times 10^{5}$ & $5.2 \times 10^{2}$ & 0.16 \\
\hline Clost. Perfringens ATCC-6013 & $1.2 \times 10^{3}$ & $3.0 \times 10^{3}$ & 0.8 \\
\hline Bifidobac. Bitidum ATCC-15696 & $5.0 \times 10^{4}$ & $5.7 \times 10^{4}$ & 114,0 \\
\hline adoleseentis ATCC 15703 & $2.0 \times 10^{8}$ & $6.3 \times 10^{4}$ & 32.0 \\
\hline breve ATCC-15700 & $4.0 \times 10^{5}$ & $4.6 \times 10^{4}$ & 12.0 \\
\hline longum ATCC-15707 & $4.8 \times 10^{5}$ & $3.1 \times 10^{4}$ & 7.0 \\
\hline infantis ATCC-15697 & $2.0 \times 10^{i}$ & $<100$ & 0.05 \\
\hline
\end{tabular}

Notes: $\mathrm{CFU}=$ Colony forming unit. The control contained no added peptides; treated contained lactoferricin B at $31 \mathrm{ug} / \mathrm{ml}(10 \mathrm{umol} /$ 1). Survival was assayed after $60 \mathrm{~min}$. of incubation. Adopted from reference [2]. 